\title{
THE EFFET OF COMPENSATION ON EMPLOYEE PERFORMANCE THROUGH WORK DISCIPLINE AS AN INTERVENING VARIABLE AT PANAHMAS DWITAMA DISTRINDO LTD. JEMBER
}

\author{
Vika Dhelia Pristiawati ${ }^{{ }^{*}}$ \\ Rahmat Agus Santoso ${ }^{2}$ \\ 1, 2 Universitas Muhammadiyah Gresik, Indonesia \\ e-mail: vikadhelia122@gmail.com ${ }^{1}$, ra_santoso@umg.ac.id ${ }^{2}$ \\ ${ }^{*}$ Correspondence: vikadhelia122@gmail.com ${ }^{1}$
}

Submitted: 19 November 2021, Revised: 11 December 2021, Accepted: 14 December 2021

\begin{abstract}
Panahmas Dwitama Distrindo Jember is a product distributor company of Unilever Indonesia Ltd. has low employee discipline and decreased productivity of employee performance is one of the problems this company faces. This study aims to see the effect of compensation on employee performance through work discipline as an intervening variable at Panahmas Dwitama Distrindo Ltd. Jember. This research method uses quantitative research methods by taking 60 respondents. Answer the problem formulation with the help of Smart Partial Least Square (PLS) 3 and analyze the data using the Partial Least Square (PLS) analysis technique. The study results show that compensation has a negative and insignificant effect on employee performance, compensation has a positive and significant effect on work discipline. Work discipline has a positive and significant effect on employee performance, and compensation has a positive and significant effect on performance. Employees through work discipline as an intervening variable.
\end{abstract}

Keywords: compensation; work discipline; employee performance. 


\section{INTRODUCTION}

The establishment of a company and factors business capital, human resources are also included in one of the most critical factors. Therefore good management and development of human resources aim to achieve company goals (Hyväri, 2016). To achieve a company's success, there needs to be an encouragement that allows employees to develop and improve their abilities and skills optimally. One way that the company can provide is with compensation. Achieving good company performance and company progress Contribute to employee performance in their respective jobs (Ardiansyah \& Bachri, 2021). According to (Priyono \& Darma, 2016), compensation is income received by employees in the form of goods directly or indirectly by the company in return for services that have been provided to the company.

Person obedience in actual behavior at the time of achieving the goals set and supported by high work discipline, then the success of a job carried out by employees of a company to obtain the maximum result. Mediation can be interpreted as a process of third party participation (third element) in solving a problem (Armengol, 2013), and here work discipline is an intermediary to determine the effect of compensation on employee performance. An employee's performance or an employee is an evaluation of the employee's work in performing their duties and responsibilities and following the procedures determined by the organization within a certain period: profitable or non-profitable (Rachmawati et al., 2021). This is also following previous research conducted by (Patmarina \& Erisna, 2012) that work discipline affects the performance of employees' CV. Laut Selatan Jaya Bandar Lampung.

Panahmas Dwitama Distrindo Ltd. is a distributor company Unilever with the status of a private company, where employees are required to have a good performance for the company to survive and compete with other companies. Therefore, companies must consider factors - factor labor that determines the company's success in achieving its goals by increasing employee performance.

Based on observations made by the author, the fact that employees of Panahmas Dwitama Distrindo Ltd. have different performances is influenced by compensation and productivity. In providing compensation to employees following the level of education, period, and career period at the company Panahmas Dwitama Distrindo Ltd. The provision of compensation based on Law No. 13 of 2003 concerning Manpower Article 1 paragraph 30 requires companies to provide salaries and wages in which there are also allowances. The contents of Law No. 13 of 2003 (Undang-Undang, 2003) concerning Manpower Article 1 Paragraph 30 is that.

"Wages are the workers' rights or workers received and expressed in the form of money as a rewarding entrepreneur or employer to the worker or laborer who is determined and paid according to an employment agreement, agreements, or statutory regulations, including allowances for 
444 | The Effect of Compensation on Employee Performance Through Work Discipline as an Intervening Variable at LTD. Panahmas Dwitama Distrindo Jember

workers or laborers and their families for a job and for services that have been or, will 'be performed."(UndangUndang, 2003).

In addition to compensation, companies can also improve employee performance by creating work discipline. Work discipline can affect employee performance, and this statement is reinforced by the opinion of (Hasibuan et al., 2017) that The better one's work discipline, the higher the performance will be achieved. The work discipline of Panahmas Dwitama Distrindo Ltd. can be seen from the attendance and punctuality when employees enter the office. This can be seen from the number of attendance achieved. The employee attendance method of Panahmas Dwitama Distrindo Ltd. Jember uses fingerprints to be precise and accurate in evaluating employee discipline.

In solving performance problems, poor work discipline is also a factor that reduces productivity, affecting performance because many employees are subject to disciplinary action. From the description above, the formulation of the problem proposed is whether compensation affects employee performance through work discipline as an intervening variable. This study aimed to determine the effect of compensation on employee performance through work discipline as an intervening variable.

\section{Compensation}

According to Priyono \& Darma (2016), compensation is all income received by employees in the form of goods directly or indirectly by the company in return for services rendered to the company. Compensation is divided into him that compensation direct and indirectly. Direct compensation is in salary, wages, intensive while compensation is indirect to inform welfare employees. In his book, Priyono \& Darma (2016) explains in detail the objectives of compensation include:

a. Cooperation Bonds, by providing compensation, a formal cooperative bond is established between employers and workers, where employees (laborers) must do their jobs well while employers are obliged to pay agreed compensation.

b. Job Satisfaction, with remuneration employees, will be able to meet their life needs so that job satisfaction will be obtained from the position they hold.

c. Motivation, If the remuneration provided is adequate, then managers will find it easier to motivate employees, which will have an impact on increasing productivity.

d. Employee Stability, with a compensation program based on fair and proper principles, guarantees employee stability because turnover is relatively small.

e. Discipline Improvement, Compensation. Following procedures will have an impact on increasing employee discipline.

\section{Work Discipline}

According to Parwita (2015), work discipline is the willingness of an employee to comply with and carry out various 
provisions that must be obeyed. (Supomo \& Nurhayati, 2018) also argue that work discipline is an attitude or behavior of employees in an organization or institution always to obey, respect, and respect all rules and norms that have been determined by the institution so that organizational goals are achieved. From the description above, it can be concluded that Work Discipline is an act of one's awareness to carry out all the regulations determined by the company so that organizational goals are achieved. According to (Farid et al., 2019), some factors that influence employee discipline, namely:

1. The amount of compensation may affect discipline. Employees will comply with all applicable rules.

2. Whether the company has exemplary leadership or not, an example of leadership is significant. Because in a corporate environment, all employees will always be vigilant about how they can control themselves with words, actions, and attitudes that they have control over, which may violate disciplinary rules.

3. Whether or not there are specific rules used as a guideline, a company cannot develop discipline without specific document rules that can be used as general guidelines.

4. The courage of leadership to act. If employees have committed misconduct, management needs the courage to act according to their misconduct level.

5. All activities conducted by the company, whether or not supervised by management, must be supervised to guide employees to perform their duties correctly following decisions made.

6. Whether you care about them or not, employees have different personalities.

7. Development habits that promote discipline.

\section{Performance}

According to (Mangkunegara, 2005) Performance is the result of work in quality and quantity achieved by an employee in carrying out his duties following the responsibilities given to him. According to (Simamora, 2004) there are several characteristics of employees who have high performance, including:

a. Achievement-oriented employees who have high performance have a strong desire to build the dreams they dream of.

b. Confidence, employees with high performance have a positive attitude that leads to acting with a high level of confidence.

c. Self-control, employees with high performance have high self-discipline.

d. Competition, employees with high performance, can develop specific abilities.

\section{The Hypothesis of Research}

Effect of Compensation on Employee Performance

Argue by (Purnama Dewi \& Harjoyo, 2019) that the purpose of compensation, in general, is to help the company achieve the goals of the company's strategy success and ensure the creation of internal and external justice. In addition, compensation 
446 | The Effect of Compensation on Employee Performance Through Work Discipline as an Intervening Variable at LTD. Panahmas Dwitama Distrindo Jember

is intended for the benefit of employees, the government, and the community. On the other hand, the compensation program must also be determined based on fair and reasonable principles to provide satisfaction for all parties, and the purpose of compensation is achieved. A previous study researched by (Junaedi \& Lestari, 2017) stated that partial compensation significantly affects employee performance at the Brilliant Education Center Probolinggo Educational Institution. At the same time, the results of research (Asmayana, 2018) Compensation has a positive effect on employee performance at the City Trade Office Makassar. Based on the statement above, the following hypothesis can be formulated:

$\mathrm{H} 1$ : Compensation has a positive effect on the performance of employees of Panahmas Dwitama Distrindo Ltd. Jember.

The Effect of Compensation on Work Discipline

Compensation is one factor that influences the enforcement of employee discipline in a company. According to (Reni Yesi, 2017), discipline is an attitude of respect for the company's rules and regulations that exist in employees, which causes employees to conform to the rules and regulations company voluntarily. The results of (Husain 2020) state a positive and significant influence between Compensation on Work Discipline of Ltd. Strategic Pest control Tebet, South Jakarta. A similar study was also conducted by (Suwarna \& Juliansyah, 2018), which stated a significant influence between Compensation on Employee Work
Discipline at Ltd. Son of the Hutama Board.

From the description above, the following hypothesis can be drawn:

H2: Compensation positively affects Employee Work Discipline at Panahmas Dwitama Distrindo Ltd. Jember.

The Influence of Work Discipline on Employee Performance

The company must create productivity in improving employee performance, starting with the first step, namely Work Discipline. By creating work discipline, employees will have high performance. (Liyas \& Primadi, 2017) in their research, work discipline has a significant effect on Employee Performance at Rural Banks.

\section{H3: Work Discipline Affects Employee Performance.}

The Effect of Compensation on Employee Performance through Work Discipline as an Intervening Variable.

The company always expects employees to have high performance. Employees with high performance improve the company's overall performance to survive and compete in global competition. The high and low level of employee performance can be seen from the compensation they get from the company. Therefore the company must provide compensation following the responsibilities given. In addition to compensation, work discipline is also a factor causing employee performance that is less than optimal in completing work on time. (Isvandiari \& Fuadah, 2017) in his research shows that compensation and 
work discipline variables significantly affect the performance of Ltd. Meritjan Kediri.

H4: Compensation positively affects employee performance through work discipline as an Intervening variable.

The research shows that updates and differences lie in the variables and population and how to process the data. The author's interest in taking the title "the effect of compensation on employee performance through work discipline as an intervening variable at panahmas dwitama distrindo Ltd. Jember" because the author wants to know and learn about compensation work discipline and employee performance. In addition, the author will also test whether there is an influence between these variables.

\section{MATERIALS AND METHODS}

The research used is approach descriptive and quantitative analysis so that the data are numbers (numeric). According to (Sugiyono, 2016) the Quantitative approach is a research method based on the philosophy of positivism used to examine populations specific or samples, data collection using instruments research, data analysis is quantitative and statistical, intending to test predefined hypotheses so that the results can find out what has been suspected. The purpose of this research using the descriptive method is to describe the object of research, or the research results can be seen clearly. (Sugiyono, 2017) also states that this descriptive research method is carried out to determine the existence of independent variable, either on one or more variables, without making comparisons of variables
Quantitative research is systematic scientific research on parts and phenomena and their relationships. The purpose of quantitative research is to develop and use mathematical models, theories, and hypotheses related to natural phenomena. The measurement process is a crucial part of quantitative research. This provides an overview or answer to the fundamental relationship of quantitative relationships (Siyoto \& Sodik 2015). Research with a quantitative approach is usually carried out with the number of samples determined based on the existing population. Calculation of the number of samples is done using a specific formula. The selection of the formula to be used is then adjusted to the type of research and population homogeneity (Priyono \& Darma, 2016).

\section{Data Collection Tools}

Quantitative data collection methods rely heavily on random sampling and instruments structured data collection according to predetermined response categories so that the resulting data is easy to summarize, compare and generalize. Quantitative research is closely related to testing hypotheses made from previous theories or an occurrence of phenomena.

\section{Population and Sample}

The population used in this study were employees of Panahmas Dwitama Distrindo Ltd. Jember. The number of employees of Panahmas Dwitama Distrindo Ltd. Jember totals 150 employees. According to (Margono 2005), the population is the entire object of research consisting of a human object, animals, plant, symptoms, test scores of the event as sources of funds that have characteristics 
448 | The Effect of Compensation on Employee Performance Through Work Discipline as an Intervening Variable at LTD. Panahmas Dwitama Distrindo Jember

specified in a study.

Most members' sample is of the population taken using the sampling method. This study uses sampling developed by Isaac and Michael using a statistical approach for an error rate of $10 \%$, which can be done with the formula:

Where:

n: Sample

$\mathrm{N}$ : Population

D: Degrees of freedom

Diet:

$\mathrm{N}: 150$ Employees

D: $10 \%$

$n=\frac{150}{150\left(10 \%^{2}\right)+1}$

$n=\frac{150}{150(0,01)+1}$

$n=\frac{150}{2,5}=60$

So the sample collection of this study only used 60 of the 150 employees of Panahmas Dwitama Distrindo Ltd. Jember.

\section{Types of Research}

This research uses descriptive research development with survey descriptive research methods. The purpose of this research is to find out the effect of compensation on employee performance through work discipline as an intervening variable at Panahmas Dwitama Distrindo Ltd. Jember.

\section{Types of Research Data}

This study uses primary and secondary data. According to (Sarwono, 2006), primary data is data in the form of text from interviews and obtained through interviews with informants sampled in his research. In connection with this research, the primary data was obtained from a questionnaire survey on employees of Panahmas Dwitama Distrindo Ltd. Jember. At the same time, the secondary data from this study were obtained from other data sources related to the research title.

\section{Nature of Research Data}

The nature of the data in this study is quantitative data. According to (Siyoto S. \& Sodik, 2015), quantitative data is data in the form of numbers or numbers. Following the form, quantitative data can be processed or analyzed using mathematical or statistical calculation techniques.

\section{Data Collection Tool}

Data collection was done through questionnaires or questionnaires as a data collection tool chosen by researchers to collect data.

\section{Data Analysis Techniques}

The data analysis technique is carried out chronologically after data collection and processed and analyzed computerized. The data analysis technique used validity test, test reliability, simple linear regression, correlation coefficient, coefficient of determination, and significant test (t-test).

\section{The approach in Data Analysis}

This study uses a systematic descriptive approach and inferential analysis of the relationship between variables by testing hypotheses.

\section{RESULTS AND DISCUSSION}

Data were managed using the partial least square (PLS) (Ghozali \& Latan, 2015). method using the Smart PLS 3.0 program. The research results can be seen as follows: 


\section{Evaluation of the Measurement Model or Outer Model}

In testing the validity and reliability, the research model can use latent constructs with indicators reflective and normative.

a. Convergent validity is determined based on the principle that the measurement of a construct should be highly correlated (Jabbour et al., 2015). The convergent validity with indicators was reflectively evaluated by Average Variance Extracted (AVE).

Table 1. Convergent Validity

\begin{tabular}{ccc} 
& Factor Loading & P-Value \\
\hline X3 & 0.887 & 0.000 \\
\hline X4 & 0.874 & 0.000 \\
\hline X5 & 0.700 & 0.000 \\
\hline Y3 & 0.884 & 0.000 \\
\hline Y4 & 0.831 & 0.000 \\
\hline Z3 & 0.823 & 0.000 \\
\hline Z4 & 0.837 & 0.000 \\
\hline Z5 & 0.846 & 0.000 \\
\hline
\end{tabular}

Source: Processed data (2021)

Based on table 1. It can be proven if the data in the study is valid because the value factor loading is more significant than 0.7.

b. Validity Discriminant aims to ensure whether an indicator reflective is correct to measure good.

Table 2. Discriminant Validity

\begin{tabular}{ll}
\hline & (AVE) \\
\hline Compensation & 0.680 \\
\hline Company Performance & 0.737 \\
\hline Work Discipline & 0.698 \\
\hline
\end{tabular}

Source: Processed data (2021)

Table 2 shows the AVE value of all variables $>0.5$, and it can be stated that all variables have good discriminant validity.

Table 3. Composite Validity

\begin{tabular}{ll} 
& Composite Reliability \\
\hline$X$ & 0863 \\
\hline$Y$ & 0848 \\
\hline$Z$ & 0874 \\
\hline
\end{tabular}

Source: Data processed (2021).

Based on table 3 above, the composite value reliability of all research variables > 0.7 , thus indicating that all variables have met the composite standard. So that all variables are considered reliable.

Table 4. Cronbach's Alpha

\begin{tabular}{ll} 
& Cronbach's Alpha \\
\hline Compensation & 0.764 \\
\hline Performance & 0.645 \\
\hline Work Discipline & 0.785
\end{tabular}

Source: Processed data (2021)

Table 4. shows The Cronbach's Alpha value $>0.6$. Performance has the lowest value of 0.645 .

\section{Evaluation of the Structural Model (Inner Model)}

After measuring (outer model), then testing the model structural (inner model). $\mathrm{R}$ Square can show the strength and weakness of the influence caused by endogenous variables (Maryani et al., 2020). The following is the R-Square value on the latent variable:

Table 5. R Square

\begin{tabular}{ll} 
& R Square \\
\hline Compensation $(X)$ & \\
\hline Performance $(Y)$ & 0.571 \\
\hline Work Discipline $(\mathrm{Z})$ & 0.212 \\
\hline \multicolumn{2}{l}{ Source: Processed data (2021) }
\end{tabular}

Based on table 5, the latent variable of 
450 | The Effect of Compensation on Employee Performance Through Work Discipline as an Intervening Variable at LTD. Panahmas Dwitama Distrindo Jember

performance has a value of 0.571 which means that performance can explain the variance of Work Discipline of $57.1 \%$. The value of $R$ Square of Work Discipline is also influenced by compensation of 0.212 , testing the hypothesis as follows:

1. Effect of compensation $(X)$ on employee performance $(\mathrm{Y})$.

2. The effect of compensation $(X)$ on work discipline (Z).

3. The effect of work discipline $(Z)$ on employee performance $(\mathrm{Y})$.

4. The effect of compensation on employee performance through work discipline as an intervening variable.

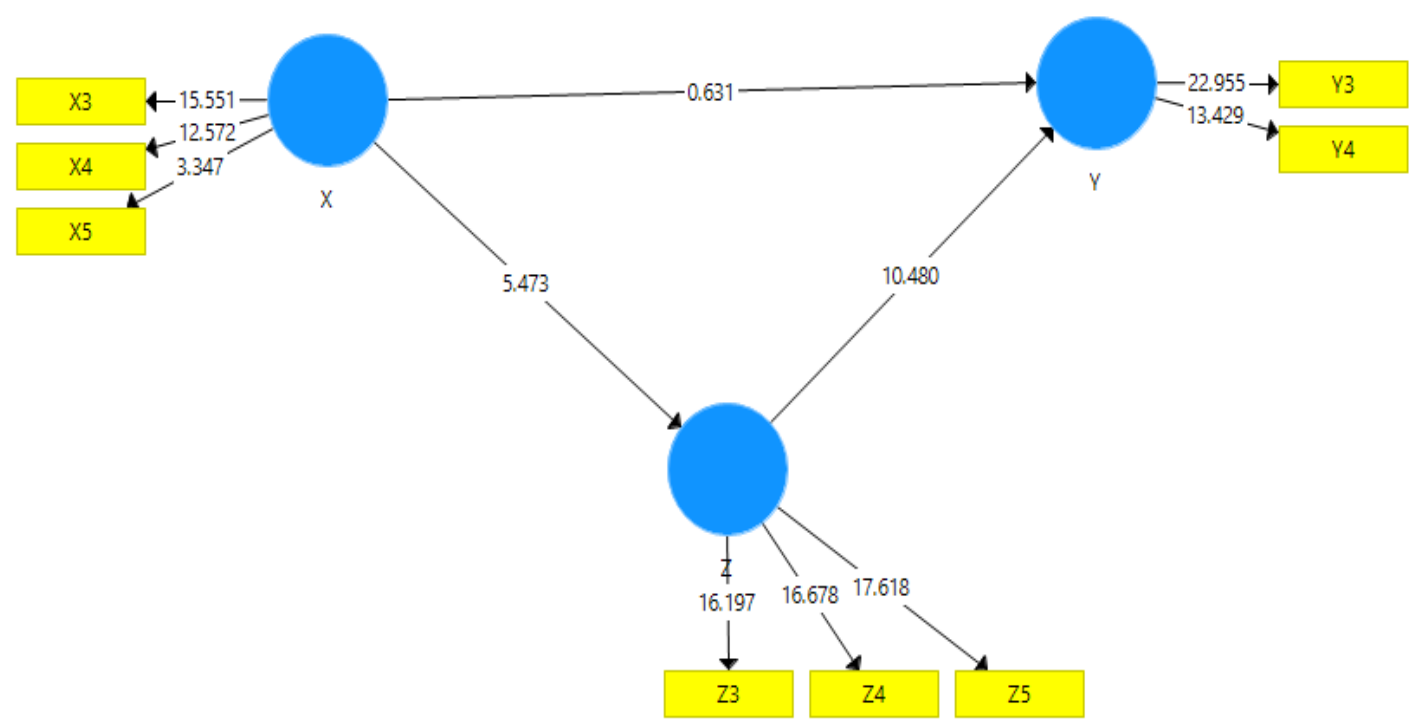

Figure 1. Path Diagram

Figure 1 is the result of processing data carried out with the SmartPLS 3.0 program, then in hypothesis testing, display the results of data processing relationships between variables using SmartPLS as follows:

Table 6. Results of Inter-Variable Influence Test

\begin{tabular}{|c|c|c|c|c|c|}
\hline & $\begin{array}{l}\text { Original } \\
\text { Sample } \\
\text { (0) }\end{array}$ & $\begin{array}{l}\text { Sample } \\
\text { Mean (M) }\end{array}$ & $\begin{array}{l}\text { Standard } \\
\text { Deviation } \\
\text { (STDEV) }\end{array}$ & $\begin{array}{l}\text { T Statistics } \\
(|\mathrm{O} / \mathrm{STDEV}|)\end{array}$ & $\begin{array}{l}\mathbf{P} \\
\text { Values }\end{array}$ \\
\hline Compensation $\quad(X) \quad->$ & -0.077 & -0.083 & 0.122 & 0.631 & 0.264 \\
\hline Employee Performance (Y) & & & & & \\
\hline $\begin{array}{l}\text { Compensation }(X)->\text { Work } \\
\text { Discipline }(Z)\end{array}$ & 0.461 & 0.493 & 0.084 & 5.473 & 0.000 \\
\hline $\begin{array}{l}\text { Work Discipline (Z) -> } \\
\text { Employee Performance }(Y)\end{array}$ & 0.788 & 0.801 & 0.075 & 10.480 & 0.000 \\
\hline
\end{tabular}


Source: Processed data (2021)

\section{Discussion}

Based on table 6, obtained p-value and t-statistics for each variable are described as follows:

\section{Effect of Compensation on Employee Performance}

Table 6 shows that the relationship between compensation and employee performance is not significant with a $\mathrm{P}$ Value of $0.264>0.05$ with a beta value of -0.007 and a T-statistic value of 0.631 $<\mathrm{t}$-table 1,96 it can be concluded that compensation has a negative and insignificant effect on employee performance. This explains that compensation has a negative and insignificant effect on the performance of employee Panahmas Dwitama Distrindo Ltd. Jember. However, employees work to meet their needs and improve their lives where compensation given by large or small companies does not improve employees' performance. This is different from previous research conducted by (Junaedi \& Lestari, 2017), which states that partial compensation significantly affects employee performance at the Brilliant Education Center Probolinggo.

\section{Effect of compensation on work discipline}

The $p$-value of the compensation variable on work discipline is $0.000<$ significant 0.05 with a positive beta value of 0.461 , and the $t$ statistic has a value of $5.473>1.96$. It can be concluded that compensation has a positive and significant effect on work discipline. This explains that compensation has an effect on employee discipline at Panahmas Dwitama Distrindo Ltd. Jember. The factor that affect the enforcement of employee discipline is compensation, so to improve employee work discipline the company must provide appropriate compensation. This research is supported by previous research conducted by (Husain, 2020) which states that there is a positive and significant influent between compensation on the work discipline of Ltd. Strategic Pest control Tebet, South Jakarta. (Suwarna \& Juliansyah, 2018) also argued that there is a significant influence between compensation on employee work discipline at Ltd. Putra Papan Hutama.

\section{Testing the effect of work discipline on employee performance}

The $p$-value of the work discipline variable on employee performance is 0.000 <significantly 0.05 with a positive beta value of 0.788 and the $t$ statistic has a value of $10.480>1.96$, it can be concluded that work discipline has a positive and significant effect on performance employee. This explains that work discipline affects the performance of employees of Panahmas Dwitama Distrindo Ltd. Jember. Employees who have high work discipline certainly have high performance as well. (Liyas \& Primadi, 2017) in previous research also produced a statement what work 
452 | The Effect of Compensation on Employee Performance Through Work Discipline as an Intervening Variable at LTD. Panahmas Dwitama Distrindo Jember

discipline had a significant effect on

employee performance at Bank Kreditan

Rakyat.
4. Testing the effect of compensation on performance through work discipline as an intervening variable

Table 7. indirect effect test results

\begin{tabular}{|c|c|c|c|c|c|}
\hline & $\begin{array}{l}\text { Original } \\
\text { Sample } \\
\text { (0) }\end{array}$ & $\begin{array}{l}\text { Sample } \\
\text { Mean } \\
(\mathrm{M})\end{array}$ & $\begin{array}{l}\text { Standard } \\
\text { Deviation } \\
\text { (STDEV) }\end{array}$ & $\begin{array}{l}\text { T Statistics } \\
\text { (|O/STDEV|) }\end{array}$ & P Values \\
\hline Compensation $(X)$-> Work & & & & & \\
\hline $\begin{array}{l}\text { Discipline }(Z) \text {-> Employee } \\
\text { Performance }(Y)\end{array}$ & 0.363 & 0.396 & 0.083 & 4.397 & 0.000 \\
\hline
\end{tabular}

Source: Processed data (2021)

Tables The above shows a $\mathrm{P}$-value of $0.000<0.05$, with a beta value of 0.363 and a t-statistic value of $4.397>$ at-value of 1.96, it can be concluded that compensation has a positive and significant effect on employee performance through work discipline as an intervening variable. This explains that the effect of compensation on company performance through employee discipline at Panahmas Dwitama, DIstrindo Jember Ltd. The first step that must be taken by the company to improve employee performance is to enforce good work discipline, for that the company must provide appropriate compensation so that employee performance increases. Previous research conducted by (Andryane \& Mukaffi, 2019) stated that compensation has an indirect effect on employee performance through work discipline at PT Telekomunikasi Indonesia.

\section{CONCLUSIONS}

Based on the research results and the hypotheses that have been formulated, the results obtained are research that is able to prove and answer this research problem. The conclusions are compensation has a negative and insignificant effect on employee performance at Panahmas Dwitama Distrindo Ltd. Jember. Compensation has a positive effect on Work Discipline Panahmas Dwitama Distrindo Ltd. Jember. Work Discipline has a positive and significant effect on Employee Performance of Panahmas Dwitama Distrindo Ltd. Jember. Compensation has a positive and significant influence on employee performance through Work Discipline as an intervening variable. Work Discipline is able to mediate the effect of compensation on the performance of employees of Panahmas Dwitama Distrindo Ltd. Jember.

\section{REFERENCES}

Andryane, R., \& Mukaffi, Z. (2019). Pengaruh kompensasi terhadap kinerja karyawan melalui disiplin kerja sebagai variabel interverning: studi kasus pada karyawan PT Telkomunikasi Indonesia TBK Witel Kediri. Jurnal Sosial Ekonomi Dan Humaniora, 2, 216-225. 
Ardiansyah, M. F., \& Bachri, A. A. (2021). Pengaruh Kepemimpinan Partisipatif, Kompensasi Dan Kepuasan Kerja Terhadap Kinerja Karyawan Divisi Coal Processing And Barge Loading-Pt Adaro Indonesia. Jurnal Indonesia Sosial Sains, 2(11), 1933-1952.

Armengol, V. F. (2013). The principles of mediation and the role of third parties in peace processes. Norwegian Peacebuilding Resource Centre Report, Sep Tember, 5.

Asmayana, H. A. (2018). Pengaruh Kompensasi Terhadap Kinerja Pegawai Pada Kantor Dinas Perdagangan Kota Makassar. Jurnal Profitability Fakultas Ekonomi Dan Bisnis, 2(2).

Farid, A., Haerani, S., Hamid, N., \& Reni, A. (2019). The Effect of Organizational Culture, Organizational Commitment and Work Satisfaction Toward Teacher Performance of High School at Makassar. Hasanuddin Journal of Applied Business and Entrepreneurship, 2(2), 89-99.

Ghozali, I., \& Latan, H. (2015). Partial least squares konsep, teknik dan aplikasi menggunakan program smartpls 3.0 untuk penelitian empiris. Semarang: Badan Penerbit UNDIP.

Hasibuan, S., Mawarni, R., \& Hendriandy, R. (2017). Respon Pemberian Pupuk Bokashi Ampas Tebu dan Pupuk Bokashi Eceng Gondok terhadap Pertumbuhan dan Produksi Tanaman Kedelai (Glycine max (L) Merril). Bernas: Jurnal Penelitian Pertanian, 13(2), 59-64.

Husain, B. A. (2020). Pengaruh Kompensasi Terhadap Disiplin Kerja Karyawan Pada PT. Strategic Pestcontrol Tebet Jakarta Selatan. JENIUS (Jurnal Ilmiah Manajemen Sumber Daya Manusia), 3(3), 277-285.
Hyväri, I. (2016). Roles of top management and organizational project management in the effective company strategy implementation. ProcediaSocial and Behavioral Sciences, 226, 108-115.

Isvandiari, A., \& Fuadah, L. (2017). Pengaruh Kompensasi dan Disiplin Kerja Terhadap Kinerja Karyawan Bagian Produksi PG. Meritjan Kediri. Jurnal Ilmiah Bisnis Dan Ekonomi Asia, 11(2), 1-8.

Jabbour, C. J. C., Jugend, D., de Sousa Jabbour, A. B. L., Gunasekaran, A., \& Latan, H. (2015). Green product development and performance of Brazilian firms: measuring the role of human and technical aspects. Journal of Cleaner Production, 87, 442-451.

Junaedi, J., \& Lestari, I. W. (2017). Pengaruh Disiplin Kerja dan Kompensasi Terhadap Kinerja yawan Pada Lembaga Pendidikan Brilliant Education Centre Probolinggo. Jurnal Ilmiah Ecobuss, 5(1), 21-32.

Liyas, J. N., \& Primadi, R. (2017). Pengaruh disiplin kerja terhadap kinerja karyawan pada bank perkreditan rakyat. Al-Masraf: Jurnal Lembaga Keuangan Dan Perbankan, 2(1), 17-26.

Mangkunegara, A. A. A. P. (2005). Evaluasi kinerja SDM. Tiga Serangkai.

Margono, S. (2005). Metodologi penelitian pendidikan.

Maryani, N. L. K. S., Widyani, A. A. D., \& Saraswati, N. P. A. S. (2020). Pengaruh Kompensasi Finansial Terhadap Kinerja Karyawan Dengan Motivasi Sebagai Variabel Intervening Pada Pt Arta Sedana Retailindo Cabang Hardys Malls Sanur Pengaruh Kompensasi Finansial Terhadap Kinerja Karyawan Dengan Motivasi 
454 | The Effect of Compensation on Employee Performance Through Work Discipline as an Intervening Variable at LTD. Panahmas Dwitama Distrindo Jember

Sebagai Variabel Inter. VALUES, 1(2), 53-67.

https://doi.org/10.35314/inovbiz.v4i2. 75

Parwita, G. B. S. (2015). Disiplin Kerja Karyawan (Suatu Kajian Teori). Jurnal Ilmu Manajemen Mahasaraswati, 5(2), 101040.

Patmarina, H., \& Erisna, N. (2012). Pengaruh Disiplin Kerja Terhadap Kinerja Karyawan Yang Dimediasi Oleh Produktivitas Kerja Perusahaan CV. Laut Selatan Jaya Di Bandar Lampung. Jurnal Manajemen Dan Bisnis, 3(1). http://dx.doi.org/10.36448/jmb.v3i1.4 93

Priyono, P., \& Darma, U. B. (2016). Buku manajemen sumber daya manusia (2). Surabaya: Penerbit Zifatama.

Purnama Dewi, D., \& Harjoyo, H. (2019). Manajemen Sumber Daya Manusia.

Rachmawati, S. N., Lumbanraja, P., \& Siahaan, E. (2021). The Effect of Adaptive Ability, Communication Skills, and Work Environment on Performance of Medan Mayor's Office with Teamwork as Intervening Variables. Journal Research of Social Science, Economics, and Management, 1(4), 406-417. https://doi.org/10.36418/jrssem.v1i4. 37

Reni Yesi, S. (2017). Analisis Pengaruh Kepemimpinan Dan Disiplin Kerja Terhadap Kinerja Pegawai PT. Karisnamas Di Bekasi. Jurnal Administrasi FIA Unija, 4(2), 28-38.

Sarwono, J. (2006). Metode penelitian kuantitatif dan kualitatif.

Simamora, H. (2004). Manajemen sumber daya manusia.

Siyoto, S. \& Sodik, M. A. (2015). Dasar
Metodologi Penelitian. Literasi Media.

Siyoto, S., \& Sodik, M. A. (2015). Dasar metodologi penelitian. Literasi Media Publishing.

Sugiyono. (2016). Metode Penelitian Kuantitatif, Kualitatif dan R\&D. PT Alfabet.

Sugiyono, P. D. (2017). Metode Penelitian Bisnis: Pendekatan Kuantitatif, Kualitatif, Kombinasi, dan R\&D. Penerbit CV. Alfabeta: Bandung.

Supomo, R., \& Nurhayati, E. (2018). Manajemen Sumber Daya Manusia.

Suwarna, A., \& Juliansyah, R. (2018). Pengaruh Kompensasi Terhadap Disiplin Karyawan Di PT. Putera Papan Hutama. Jurnal Ilmiah MEA (Manajemen, Ekonomi, \& Akuntansi), 2(1), 30-41.

Undang-Undang, R. I. (2003). Nomor 13 Tahun 2003. Tentang Ketenagakerjaan.

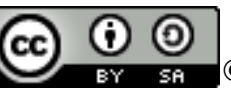

C 2021 by the authors. Submitted for possible open-access publication under the terms and conditions of the Creative Commons Attribution (CC BY SA) license (https://creativecommons.org/licenses/by-sa/4.0/). 